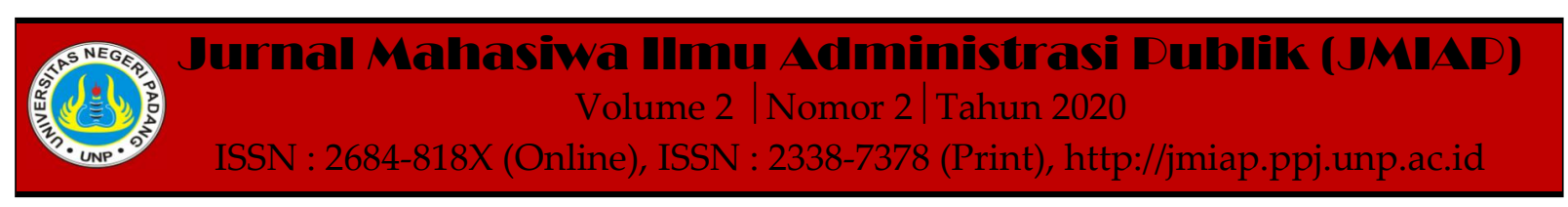

\title{
EVALUASI IMPLEMENTASI KEBIJAKAN PENGELOLAAN KELESTARIAN KAWASAN DANAU MANINJAU DI KABUPATEN AGAM
}

\author{
Cindera Billova ${ }^{1(a)}$, Adil Mubarak ${ }^{2(b)}$ \\ ${ }^{1}$ Jurusan Ilmu Administrasi Negara, Universitas Negeri Padang \\ ${ }^{2}$ Jurusan Ilmu Administrasi Negara, Universitas Negeri Padang \\ a)cinderabillova2598@gmail.com, ${ }^{\text {b) }}$ adilmubarak08@yahoo.co.id
}

\begin{abstract}
The purpose of this research is to evaluate or assess the implementation of policy whether the policy has been running optimally and whether the policy is feasible to proceed. This research is qualitative research with descriptive method. The selection of speakers is done by purposive sampling. Data collection is done by interview and documentation studies, to analyze the data is done by presenting data, data reduction, and data verification. The instrument used in this study was the researcher himself, for guiding interviews using several questions that had been prepared, while to support documentation related to the research, the data collection tool used was Mobile, which serves to record which makes it easy to compile data and the validity of the data is done by source triangulation method. So, it can be concluded that the results of this study are that the policy for the management of Lake Maninjau sustainability has not been running optimally and the objectives of the policy have not yet been reached.
\end{abstract}

Keywords : Evaluation, Implementation, Sustainability of Lake Maninjau

Corresponding author. Email.cinderabillova2598@gmail.com, adilmubarak@fis.unp.ac.id

How to cite this article. Billoca, C \& Mubarak, A. (2020). Evaluasi Implementasi Kebijakan Pengelolaan Kelestarian Kawasan Danau Maninjau di Kabupaten Agam. Jurnal Mahasiwa Ilmu Administrasi Publik (JMIAP) Jurusan Ilmu Administrasi Negara Fakultas Ilmu Sosial Universitas Negeri Padang, Volume 2 (2), Hal. 54-61.

http://jmiap.ppj.unp.ac.id

ISSN : 2684-818X (Online), ISSN : 2338-7378 (Print)

Copyright(C2020. Published by Pusat Kajian-Pemberdayaan dan Pelayanan Masyarakat (PK-P2M) FIS UNP Padang 


\section{PENDAHULUAN}

Pencemaran yang terjadi di Danau Maninjau dikarenakan meningkat pesatnya pertumbuhan Keramba Jaring Apung (KJA). Dalam upaya melestarikan sumber daya alam Danau Maninjau, Pemerintah Daerah bersama DPRD Kabupaten Agam sudah membuat Peraturan Daerah Kabupaten Agam Nomor 5 Tahun 2014 Tentang Pengelolaan Kelestarian Kawasan Danau Maninjau (Limnologi, 2020).

Tujuan dari Peraturan Daerah tersebut ialah agar dapat menciptakan kawasan danau yang berbudaya, bersih, berkelanjutan dan lestari. Akan tetapi observasi awal yang dilakukan oleh peneliti mendapatkan belum tercapainya tujuan dari Perda tersebut. Dahulu, kebersihan Air Danau Maninjau bisa dimanfaatkan guna kebutuhan sehari-hari sekarang sudah tidak dapat digunakan lagi. Berdasarkan wawancara pada tanggal 20 januari 2020 di Dinas Perikanan Kabupaten Agam menemukan kandungan amoniak di Danau Maninjau yang sudah mencapai $0,037 \mathrm{mg}$ per liter, yang mana seharusnya $0,02 \mathrm{mg}$ per liter, sedangkan untuk kesadaran Cs Co juga berada pada angka 7.05. oleh karena itu Danau Maninjau Sudah mengalamai kerusakan akibat KJA yang melebihi kapasitas. Selain dikarenakan oleh KJA, kualitas air Danau Maninjau juga dikontaminasi oleh tanaman Eceng Gondok serta sampah rumah tangga.

Namun pertumbuhan Keramba Jaring Apung dikarenakan terdapat investor yang memodali dana untuk membuat Keramba Jaring Apung, serta warga juga hanya menjadi pekerja serta merawat Keramba Jaring Apung di danau. kebijakan yang telah diatur oleh pemerintah daerah disangkal oleh masyarakat, sebab kebijakan yang dibuat dianggap dianggap mengurangi pendapatan masyarakat. Kebijakan yang disusun oleh pemerintah seperti peraturan yang mengurangi banyak KJA. Bila Keramba Jaring Apung kurangi dan dibatasi maka mata pencaharian masyarakat akan berkurang. Akibat yang lebih fatalnya adalah masyarakat kehilangan mata pencaharian. Bantahan serta Penolakan oleh masayarakat yang cemas kehilangan mata pencaharian.

Berdasarkan fenomena yang peneliti dapatkan yakni, pertumbuhan KJA yang pesat di Danau Maninjau, Kurangnya Kebersihan Pada Danau Maninjau, kerusakan Danau Maninjau, hilangnya mata pencaharian masyarakat. Maka peneliti memilih fokus penelitian pada bagaimana "Evaluasi Implementasi Kebijakan Pengelolaan Kelestarian Kawasan DanauManinjau".

\section{TINJAUAN PUSTAKA}

\section{Konsep Implementasi Kebijakan Publik}

Van Meter dan Van Horn menjelaskan bahwa Implementasi kebijakan ialah kegiatan-kegiatan yang dilaksanakan oleh individu, pejabat, kelompok pemerintah ataupun swasta yang diharapkan agar tercapainya tujuan yang sudah ditetapkan didalam kebijakan dapat tercapai (Agutino, 2008). Hal-hal yang bertindak dalam pelaksanaan Kebijakan Publik bentuk implementasi kebijakan George C. Edward III dengan memakai ancangan top down agar dapat menganalisis implementasi kebijakan metode ini berpatok kepada 4 aspek yang dianggap menguasai jalan implementasi kebijakan, ialah: komunikasi, sumberdaya, disposisi, serta struktur birokrasi (Subarsono, 2011). Implementasi merupakan istrumen yang begitu penting bagi pemerintah sebagai implementator dalam mencapai tujuan-tujuan dan kesepakatan program yang telah di sepakati atau yang telah dirumuskan (Mubarak, 2012).

\section{Konsep Evaluasi Kebijakan Publik}

Suatu kebijakan tidak bisa di biarkan saja. Kebijakan mesti diawasi, serta salah satu prosedur pengawasan itu dikatakan seebagai evaluasi kebijakan (Nugroho, 2014). Evaluasi umumnya dilakukan agar dapat melihat sejauh mana keberhasilan suatu kebijakan publik agar dipertanggungjawabkan terhadap hukum yang berlaku. Dengan Adanya indeks 
Evaluasi Kebijakan agar dapat Mengevaluasi akibat suatu kebijakan dibutuhkan adanya suatu tolok ukur untuk melihat kefektifan kebijakan ataupun program publik tersebut. Indikatorindikator evaluasi kebijakan meliputi 6 indikator ialah, Efektivitas, Efisiensi, Kecukupan, Perataan, Responsivitas, Ketepatan (Dunn, 2003).

\section{Perda Kabupaten Agam Nomor 5 Tahun 2014 Tentang Pengelolaan Kelestarian Kawasan Danau Maninjau.}

persoalan lingkungan ialah suatu hal yang ruwet yang acap terjadi dalam kehidupan ber masyarakat. Pencemaran serta Kerusakan lingkungan Danau Maninjau merupakan fokus utama bagi Pemerintah untuk melaksanakan wewenang dan kebijakan dalam menerpakan pengawasan terhadap kerusakannya serta pencemaran. Tujuan dari pengelolaan kawasan danau ialah agar dapat menghasilkan kawasan danau yang lestari, bersih, berbudaya serta berkelanjutan, sedangakn Fungsi Pengelolaan kawasan danau ialah agar menjaga kelestarian SDA serta kesejahteraan warga secara merata dan berkelanjutan. Untuk bisa mencapai tujuan dari Perda tersebut Pemerintah Daerah bersama DPRD Kabupaten Agam telah menyusun Perda Kab. Agam Nomor 5 Tahun 2014 Tentang Pengelolaan Kelestarian Kawasan Danau Maninjau (Peraturan Daerah Kabupaten Agam Tentang Pengelolaan Kelestarian Danau Maninjau, 2014).

Isi dalam Perda tersebut, menjelaskan agar dapat mewujudkan tujuan yang di inginkan terdapat 6 langkah yang harus dilaksanakan oleh implementor yaitu pada bab 3 bagian pengelolaan yaitu perencanaan, pemanfaatan, pemulihan, pelestarian, mitigasi, pengawasan, pengendalian, serta Lembaga pengelola.

\section{METODE PENELITIAN}

Peneletian ini bersifat kalitatif dan mamakai metode deskriptif. Metode kualitatif ialah cara penelitian yang berpedoman pada postpositivisme agar dapat mempelajari atas keadaan sasaran alamiah, yang mana peneliti ialah menjadi alat kunci, teknik dalam pengambilan data dilakukan dengan cara teriangulasi (gabungan), dan analisis menggunakan kualitatif ataupun induktif, serta hasil penelitian dari kualitatif memfokuskan arti ketimbang generalisasi (sugyono, 2012).

Lokasi penelitian ini ialah di sekitar Danau Maninjau Kec. Tanjung Raya Kabupaten Agam dimana lokasi ini merupakan fokus pemerintah daerah Kabupaten Agam dalam implemenatsi pengelolaan kelestarian Danau Maninjau. penyebab penulis menjadikan lokasi ini sebagai tenmpat penelitian ialah penulis banyak menemui masalah didalam evaluasi implementasi kebijakan kebijakan Kengelolaan Kelestarian Kawasan Danau Maninjau. Agar kebijakan dapat dikelola dengan baik maka pemerintah daerah menyiapkan tim penyelamat Danau Maninjau (Sk Bupati No 76 Tahun 2018 Tentang Tim Penyelamatan Danau Maninjau, 2018).

\section{HASIL DAN PEMBAHASAN}

\section{Implementasi Kebijakan Pengelolaan Kelestarian Kawasan Danau Maninjau}

Agar mencapai tujuan dalam implementasi suatu kebijakan, Edward III menyatakan ada 4 faktor yaitu komunikasi, sumber daya, disposisi dan struktur birokrasi.

\section{a) Komunikasi}

Komunikasi yang dilakukan dalam implementasi kebijakan pengelolaan kelestarian Danau Maninjau ini dengan sosialisasi. Sosialisasi merupakan hal penting dalam mengenalkan kebijakan tersebut kepada masyarakat. karena adanya sosialisasi masyarakat dapat mengetahui kebijakan tersebut. Dalam implementasi kebijakan ini yang menjadi targetnya adalah petani KJA dan masyarakat, maka dari itu sosialisasi amat penting dilaksanakan agar dapat memberitahukan mengenai Perda 
kelestarian Danau Maninjau kepada masyarakat.

Tranasmisi komunikasi yang bagus akan menciptkan implementasi yang bagus. Didalam pengimplementasian kebijakan pengelolaan kelestarian danau maninjau yang laksanakan oleh Dinas Lingkungan Hidup dan Dinas Perikanan dan Ketahanan Pangan Kabupaten Agam yang merupakan leading sector dalam implementasi kabijakan kelestarian Danau Maninjau dan beberapa dinas lainnya yang ada pada SK Bupati No 76 Tahun 2018 tentang Tim Terpadu Penyelamatan Danau Maninjau.

Berhubungan dengan komunikasi dengan beberapa dinas dalam implementasi kebijakan Pengelolaan Kelestarian Danau Maninjau, terdapat adanya komunikasi yang baik antara dinas tersebut untuk komunikasi yang dilaksanakan oleh OPD selama ini sudah lumayan baik. Dan juga dapat ditingkatkan lagi dan menschedule rapatnya dan sosisalisasi kepada masyarakat agar pelaksanaan Perda Lebih efektif. tetapi masih ada masyarakat yang merasa kurang jelasnya komunikasi mengenai kebijakan ini.

Dalam implementasi kebijakan kelestarian Danau Maninjau komunikasi yang dilaksanakan oleh Dinas Lingkungan Hidup dan Dinas Perikan dan Ketahanan Pangan Kabupaten Agam kepada masyarakat melalui sosialisasi ke semua Nagari yang ada di sekitar Danau Maninjau, bentuk sosialisasi ini dilaksanakan dengan penyuluhan dihadari masyarakat yang mempunyai mata pencaharian sebagai petani tambak atau petani KJA, pengumuman / penghimbauan, dan lomba foto di media sosial. Sosialisai ini diikuti oleh oleh Wali Nagari, Satpol PP, Pemadam kebakaran, camat serta masyarakat di Nagari tersebut.

Akan tetapi dalam sosialisasi yang diberikan terbilang belum maksimal, lantaran masih ada hambatan, dimana bisa dilihat dari kejelasan dan konsitesnsi implementor dalam melaksanakan komunikasi. Masih adanya masyarakat yang tidak tahu dengan kebijkan pengelolaan kelestarian kawasan Danau Maninjau ini dan dalam menyampaikan Perda ini masyarakat menginginkan dijelsakan perpasal agar dapat dimengerti dan tidak terjadi kesalahpahaman.

\section{b) Sumber daya}

Indikator sumber daya manusia pada sumber daya kebijakan yang diungkapkan oleh George C Edward III terkait dalam pengimplementasian kebijakan Pegelolaan Kelestarian Danau Maninjau sudah memadai dilihat dari kapasitas sumber daya manusianya. Selain itu penerapan kebijakan Pegelolaan Kelestarian Danau Maninjau yang diimplementasikan mengaitkan sejumlah OPD terkait sesuai dengan tugas dan fungsinya, membentuk setiap tindakan yang dilakukan dilaksanakan oleh OPD tersebut yang menjadi tugas dan fungsi mereka.

Sedangkan sumber daya finansial atau anggaran yang ada diperkirakan dalam pelaksanaa kebijakan Pegelolaan Kelestarian Danau Maninjau untuk pelestarian kawasan Danau Maninjau membutuhkan biaya yang sangat banyak. Masalah ini dibuktikan dengan adanya biaya yang di kemukan oleh Dinas Lingkungan Hidup untuk kelestarian Kawasan Danau Maninjau. Karena itu Bupati dan Wakil Bupati membuat presenstasi di depan Gubernur maupun di depan Menteri Lingkungan Hidup. Selanjutnya adalah sumber daya sarana dan prasana yang dimiliki pelaksana.

Sarana dan prasarana yang dipunyai oleh implementor untuk medapatkan tujuan kebijakan Pegelolaan Kelestarian Danau Maninjau tidak lengkap karena implementor membutuhkan sejumlah alat guna mengisap sedimen yang berada di Danau Maninjau. Akan tetapi masih ada sejumlah yang belum mencukupi untuk pelaksana dalam pelaksanaan perubahan sikap pada masyarakat yang menjadikan KJA sebagai pekerjaan utama. 
c) Disposisi

Dalam melaksanakan suatu impelemtasi kebijakan, karakteristik pelaksana harus dilihat karena jika karakter yang ada pada pelaksana itu baik, maka dalam melaksanakan kebijakan tersebut akan baik pula. Jika perhatikan dari pelaksanaan kebijkan pengelolaan dan kelestarian Danau Maninjau Disposisi pelaksana merupakan variabel yang lumayan kondusif untuk terlaksananya peraturan daerah dan mendukung pencapaian tujuan peraturan daerah tersebut. akan tetapi peneliti juga melihat ada penolakan dari pemerinah daerah atas apa yang telah di tetapkan pemerintah provinsi. Selain itu Dengan melibatkan banyak dinas seusai dengan SK Bupati Nomor 76 tahun 2018. Setiap dinas mengimplementasikan kegiatan sesuai dengan tugas dan pokok masing-masing, karena itu untuk kesehatan diberikan kepada Dinas Kesehatan mendatangkan karakter pelaksana yang hanya akan melaksanakan apa yang harus menjadi tugas dan fungsinya.

Tidak hanya itu kekurangan anggaran dana ikut memberikan akibat kepada sikap pelaksana dapat dilihat dengan tidak adanya anggaran sejak tahun 2016 membuat kelompok kerja yang biayanya diberikan melalui Dinas Kesehatan tidak memiliki kegiatan atau tidak melaksanakan tupoksi dengan baik. Selain itu Dinas Lingkungan Hidup juga merasakan tanggung jawab kerja yang semakin bertambah dari yang sebelumnya namun untuk anggaran tambahan masih saja tidak dikeluarkan.

\section{d) Struktur Birokrasi}

Struktur birokrasi memiliki pengaruh yang besar dalam melaksanakan kebijakan, yang mana sturktur birokrasi mempunyai 2 hal penting yaitu struktur organisasi serta mekanisme implementor itu sendiri. prosedur program harus melalui standar oprational procedur (SOP). Implementasi kebijakan penglolaan kelestarian kawasan Danau Maninjau adalah arahan langsung dari Bupati. Oleh karena itu kebijakan ini merupakan berada pada naungan Dinas
Perikanan dan Pangan Pangan dan Dinas Lingkungan Hidup dan Dinas Perikanan Kabupaten agam yang merupakan leading sector.

Dalam implmentasi peraturan daerah ini mengaitkan beberapa dinas yang memiliki tugas, pokok dan fungsi yang berbeda berlandasakan tugas pokok serta fungsi mereka dalam kebijakan ini, membentuk rentang kendali yang luas. Maka dari itu dalam pelaksanaan kebijakan ini dengan melibatkan banyak Organisasi Perangkan Daerah (OPD) dan pelaksana terkait yang belum didukung dengan terdapat struktur atau rentang kendali yang belum efisien dan efektiv. Supaya hal ini dapat memberikan bentuk komunikasi antar pelaksana kebijakan.

\section{Evaluasi Peratuaran Daerah Kabupaten Agam Nomor 5 Tahun 2014 Tentang Pengelolaan Kelestarian Kawasan Danau Maninjau}

Evaluasi kebijakan ialah perbandingan mengenai kebijakan ataupun program agar dapat memahami keberhasilan dari kebijakan agar dapat dilihat tanggung jawabnya terhadap hukum yang berlaku (Mubarak, 2019). Ada 6 kriteria evaluasi kebijakan menurut William N. Dunn, Yakni:

\section{a) Efektivitas}

Ketika setelah implementasi kegatan kebijakan pubik dampaknya tidak dapat menyelesaikan masalah yang dialami masyarakat, jadi bisa dibilang bahwa suatu kebijakan tidak efektif dan gagal, namun biasanya kebijakan publik tidak dapat dilihat dalam jangka sebentar, karena akan membutuhkan suatu proses. Pelaksanaan kebijakan Pengelolaan Kelestarian Danau Maninjau dilaksanakan berdasarkan dengan isi dan tujuan yang telah diatur, isi Perda ini juga harus dilakukan dengan tegas dan jelas. Ketegasan serta kejelasan isi kebijakan tersebut bertujuan supaya dalam pelaksanaannya tidak mengalami kesalahpahaman baik untuk implementor ataupun kelompok target implementasi 
Peratuan Daerah. Implementasi kebijakan wajib dilaksanakan berdasarkan dengan isi dan tujuan kebijakan serta dilaksanakan secara jelas dan tegas.

Tujuan serta sasaran dari Perda Kabupaten Agam Nomor 5 Tahun 2014 yaitu pengelolaan Danau Maninjau terdiri dari tujuan umum yaitu menghasilkan kawasan danau yang berbudaya, bersih, lestari, dan berkelanjutan. Tidak hanya dari segi fisik saja tapi juga perubahan perilaku masyarakat yang menggunakan kawasan danau, tidak hanya itu juga mencakup pada area dekat danau serta pemanfaatannya yang baik sehingga mendapatkan danau yang lestari lagi.

Para pelaksana sudah mengetahui serta memahami secara jelas keadaan seperti apa yang di harapkan dalam penerapan Peraturan Daerah ini. Akan tetapi, dalam mengimplementasikan Perda ini, terdapat beberapa hambatan yang harus dihadapi yaitu keterbatasan anggaran dana dan sarana prasarana, tidak jelasnya zonasi untuk KJA, Peraturan yang dikeluarkan oleh pemerintah masih dibantah oleh beberapa masyarakat kususnya petani KJA karena merasa di rugikan. Sehingga menyulitkan implementor untuk menggapai tujuan yang diinginkan sesuai dengan Peraturan Daerah Nomor 5 Tahun 2014 tentang pengelolaan kelestarian Kawasan Danau maninjau.

\section{b) Efisien}

Efisiensi umumnya dilihat melalui ancangan anggaran per bagian produk kebijakan yang menggapai efektivitas tinggi dengan anggaran terendah disebut efisien. Hal yang dilakukan pemerintah Kabupaten Agam untuk mendaptkan hasil yang diinginkan adalah dengan menyusun kebijakan penyelamatan Danau Maninjau melalui 10 Agenda Prioritas Penyelamatan Danau Maninjau.

Dari 10 agenda itu, hanya beberapa agenda yang terlaksana. Pembersihan permukaan Danau Maninjau, penyelamatan biota endemik dengan melepaskan sebagian biota oleh Dinas Perikanan dan Ketahanan pangan Kabupaten Agam. Akan tetapi agar dapat melakukan pengerukaan di Danau Maninjau tidaklah mudah, di butuhkan anggaran yang besar. Berdasarkan Hasil Perhitungan pemerintah Kabupaten Agam, diperlukan sekitar Rp.55.881.500.000,- per tahun. sedangkan operasional pada tahun berikutnya biayanya tidak terlalu besar sebab tidak membutuhkan biaya pembelian alat serta fasilitas pendukung yang lain. Tidak hanya biaya penyedotan sedimen di Danau Maninjau yang memerlukan anggaran yang besar. Oleh sebab itu pemerintah Kabupaten Agam meminta dukungan berupa bantuan dana dari pemerintah pusat ataupun dari pemerintah provisi mengenai dengan pelestarian kawasan Danau Maninjau.

c) Kecukupan

Jika hubungkan dengan Peraturan Daerah Nomor 5 Tahun 2014 tentang Pengelolaan Kelestarian danau Maninjau, maka agar dapat mencapai tujuan kebijakan pengelolaan kelestarian kawasan danau maninjau, pelaksana sudah melakukan pengawasan berbentuk kegiatan razia terhadap KJA di Danau Maninjau serta membersihan kawasan Danau Maninjau. Namun penindakan yang dilaksanakan sering bocor dan diketahui warga. Tidak hanya itu bisa dibuktikan dengan struktur atau rentang kendali yang lumayan panjang mengakibatkan komunikasi yang dilaksanakan juga menjadi panjang dan lama. Hal ini juga pastinya akan memerlukan waktu yang lumayan panjang hingga informasi yang diberikan dapat dimengerti secara tepat dan jelas oleh semua pelaksana yang terkait.

\section{d) Perataan}

Melaksanakan suatu kebijakan haruslah mempunyai keadilan dalam arti seluruh sector dan dari warga harus bersama-sama bisa merasakan hasil kebijakan. Sebab fasilitas public ialah fasilitas birokrasi kepada warga untuk dapat penuhi kegiatan masyarakat.Suatu program tertentu bisa jadi 
dapat efisien, efektif, serta memadai jika biaya manfaat menyeluruh dan merata.

Agar tidak menghilangkan dan mnerugikan mata pencaharian masyarakat terutama petani KJA maka pemerintah Kabupaten Agam melaksanakan suatu program yakni Tranformasi ekonomi yang mana Tranformasi ekonomi ini bisa mengalihkan mata pencaharian masyarakat Danau Maninjau. Berdasarkan pada hasil penelitian, Transformasi ekonomi ini diberikan kepada semua warga di sekitar Danau Maninjau baik warga maupun petani KJA. Perubahan mata pencaharian ini bertujuan agar dapat mengurangi KJA di Danau Maninjau, karena adanya tranformasi ekonomi masyarakat juga mendapatkan kesejahteraan dan ketentraman kehidupan mereka.

\section{e) Responsivitas}

Berdasarkan penelitian di skitara Danau Maninjua, Sebagian masyarakat sangat menyetujui kebijakan ini sebab memang sudah seharusnya Danau maninjau dibersihkan secara maksimal hal itu dikarenakan keadaan danau yang belum membaik sampai saat ini.

Sebagian masyarakat tidak setuju dengan kebijakan ini karena merasa di rugikan, disebabkan mereka beranggapan KJA itu sebagai mata pencaharian utama dan tidak semua warga memiliki lahan pertanian.

\section{f) Ketepatan}

Berdasarkan penelitian kebijakan pengelolaan kelestarian Danau Maninjau ini sudah lah tepat, dimana tujuan dari Peraturan Daerah ini agar menciptakan dan mencapai kawasan danau yang bersih, berkelanjutann lestari, serta berbudaya yang hasilnya nanti untuk masyarakat Maninjau, untuk kita bersama dan masa depan. Akan tetapi perda tersebut belum terlaksana dengan maksimal dikarenakan masih ada faktor yang mempengaruhi perda tersebut belum berjalan dengan baik, yaitu penzonasian. Akan lebih mudah jika zonasi sudah dibuat. Untuk mewujudkannya kebijakan ini, semuanya harus dilakukan bersama, harus ada kerja sama antara implementor dan masyarakat setempat agar tujuan tercapai dengan efektif dan efisien.

\section{PENUTUP}

Peraturan Daerah Kabupaten Agam Nomor 5 Tahun 2014 Tentang Pengelolaan Kelestarian Kawasan Danau Maninjau adalah satu diantara ciptaan hukum yang susun oleh pemerintah Kabupaten Agam agar dapat melestarikan kawasan Danau Maninjau. Perda ini bermaksud untuk melestarikan kawasan Danau Maninjau yang tidak bersih seperti dulu. kerusakan di Danau Maninjau diaikibat Keramba Jaring Apung yang banyak di Danau Maninjau.

Beralaskan dari hasil riset berbentuk wawancara peneliti bersama berupa dokumentasi serta narasumber peneliti yang berhubungan dengan evaluasi implementasi kebijakan Kelestarian Kawasan Danau Maninjau, dan pengkajian menyangkut masalah yang dihubungkan dengan model implementasi Edwar III dan William Dunn, jadi bisa disimpulkan Evaluasi implementasi kebijakan kelestarian Kawasan Danau Maninjau belum tercapai secara maksimal yang dapat dilihat dari adanya perkembangan pesat Keramba Jaring Apung di Danau Maninjau.

Keramba jaring apung semakin bertambah disebabkan terdapat inevetasi ilegal yang memberikan modal kepada warga agar dapat mendirikan KJA. Keramba Jaring Apung yang terus berkembang yang mana KJA ialah pencaharian utama masyarakat di Danau Maninjau. Dilapangan penulis masih menemukan kendala yang dapat dilihat sampai tahun 2020 masih terdapat KJA yang melebihi daya tampung padahal sudah diatur di dalam Peraturan Daerah. KJA masih belum terkendali sebab tidak terdapat zonasi mengenai posisi KJA di Danau Maninjau. Jadi Perda belum dilaksanakan secara maksimal. 


\section{DAFTAR KEPUSTAKAAN}

Agutino, L. (2008). Dasar-Dasar Kebijakan Publik. CV. Alvabeta.

Dunn, wiliam n. (2003). Analisis Kebijakan Publik. Gadjah Mada Universiti Press.

Meoleong, lexy J. (2005). Metodologi Peneltian Kulaitatif Edisi Revisi. Remajarosdakarya.

Mubarak, A. (2012). Model Impelementasi Program dalam Upaya Pencapaian Sasaran MDGs 2015 (Strategi Bagi Birokrasi Sebagai Ujung Tombak Implementasi 8 sasaran MDGs). Universitas Terbuka, 1-14.

Nugroho, R. (2014). PUBLIC PILICY; Teori,Manajemen, Dinamika, Analasis, Konvergensi, dan Kimia Kebijakan. PT Elex Media Komputido.

Peraturan daerah kabupaten agam tentang pengelolaan kelestarian danau maninjau, (2014).

SK bupati no 76 tahun 2018 tentang tim penyelamatan danau maninjau, (2018).

Subarsono. (2011). Analisis Kebijakan Publik: Konsep, teori dan Aplikasi. Pustaka Pelajar.

Sugyono. (2012). Metode Penelitian Pendidikan (Pendekatan Kuantitstif, Kualitatif, dan $R \& D$. alfabeta.

Suryani, \& Hendriyani. (2016). Metode Riset Kuantitatif: Teori dan Aplikasi Pada Penelitian Bidang Manajemen dan Ekonomi Islam. kencana. 